PETER CRONAU

A Sydney journalist who works for the $A B C$ Four Corners investigative programme.

\section{Correcting the myth of East Timor}

Reluctant Saviour: Australia, Indonesia and the Independence of East Timor, by Clinton Fernandes, 2004. Melbourne: Scribe Publications. 138 pp. ISBN 1920769285

$\mathrm{T}$ HE MEDIA are willing partners in the creation of myths. In Australia, the 'Anzac Cove' and 'Don Bradman' stories have been writ large. All usually told without much reference to the political context, or to the alternate histories that might also be explained.

Usually the cue is taken from some major figures giving their analysis of an event, and the media just takes a big megaphone to amplify the view. But should it be so? Shouldn't the media be trying to deconstruct the line being offered?

Many good journalists do try to tell the public the truth about key
Tis in-depth account is challenging and instructive'- Noam Chomsky

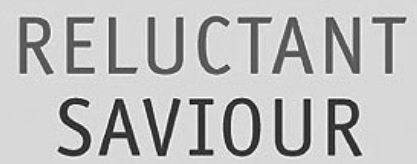

Australia, Indonesia and the independence of East Timor

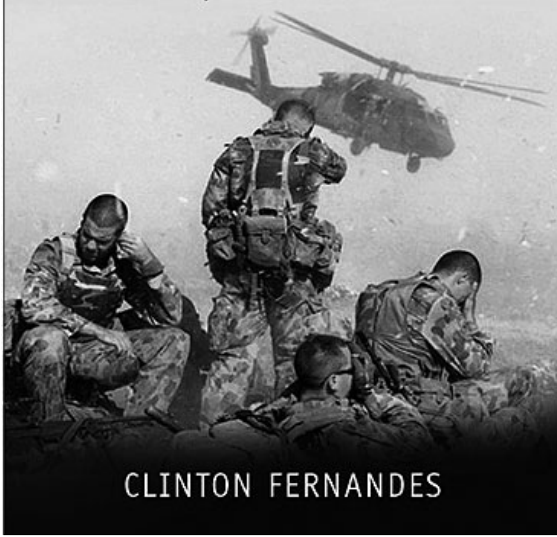

public stories. This is particularly important with more contemporary stories - such as the truth about refugees who never threw their children overboard, the non-existent weapons of mass destruction used to justify Australia's participation in the Iraq invasion, and one other myth that has remained largely unchallenged in the media, that of the late 1990s role of the Australian Government in the liberation of East Timor.

The world knows that the Australian Liberal Government in 1999 liberated the East Timorese from 24 years of Indonesian occupation, right? That's certainly the line served up by 
Prime Minister John Howard when he claimed it as the Australian Government's greatest source of pride:

The story of Australia at the moment is a story of immense achievement of great strength and enormous pride. I don't think this country has stood taller and stronger in the chanceries of the world than it does at the present time. ... Above all the achievement of bringing to the people of East Timor the freedom that they had the opportunity of voting for and they voted for so overwhelmingly.... that is a source of enormous strength to this country and a source of very great pride and it reflects enormous credit on the Coalition Government (Howard, 1999).

That is normally pretty much it. That is the story that has been peddled by repeated media stories, by prominent rightwing columnists, and by the Liberal Government itself. But with thousands dead, and the infrastructure of East Timor destroyed, all at the hands of the Indonesian military, and their proxies, there is a lot more to it. The Australian INTERFET troops who deployed to East Timor certainly deserve the greatest praise for actually securing a peace in Timor. The extent of death and destruction happened significantly because the Australian Government had accepted the Indonesian provision of security for the independence vote, despite much advice and evidence against this.

The Howard Government's position on post-Suharto East Timor was visible early on, in the letter he sent to new President Habibie in December 1998. It came as an attempt to counter a new policy initiative crafted by Labor Shadow Foreign Minister, Laurie Brereton and his adviser $\mathrm{Dr}$ Phillip Dorling, to dump Labor's longheld policy supporting Indonesian occupation.

The letter was leaked to many journalists at the time, but remained fairly inaccessible to the public till only recently. Shame, as it tells the story of the Howard Government's real intentions on East Timor:

My dear President, ... I want to emphasise that Australia's support for Indonesia's sovereignty is unchanged. It has been a long-standing Australian position that the interests of Australia, Indonesia and East Timor are best served by East Timor remaining part of Indonesia. ... It might be worth considering a means of addressing the East Timorese desire for an act of self-determination in a manner that avoids an early and final decision on the future status of the province.... [This] would allow time to convince the East Timorese of the benefits of autonomy within the Indonesian republic (1998). 
The letter, contrary to most media reports that still depict it as a request to the Indonesians for independence for East Timor, was actually a bold attempt to help Indonesia retain its hold on East Timor. Dispelling this myth is the theme of an important new work, Reluctant Saviour, by Melbourne historian and former military analyst, Clinton Fernandes.

By trawling through the public record of the events of the time, Fernandes has amassed a convincing collection of little-known evidence showing just how reluctant the Australian Government was to assist the Timorese. He has used often obscure examples, passed-over by the media at the time, to show the true intent of the government.

The book shows one of Australia's most senior diplomats, DFAT Deputy Secretary John Dauth, now Australia's ambassador to the UN, at a Senate hearing in 1999, confirming that Howard's letter was designed as an effort to strengthen Indonesia's hold on East Timor:

A very important part of our thinking at the time that the Prime Minister dispatched his letter, was that Indonesia really had only one last chance to keep East Timor as part of Indonesia (Senate References Committee, 1999).
That 'last chance' involved Australia arguing on Indonesia's behalf in public forums and in the media that the Indonesian generals could be trusted - despite their blood-soaked reputation, and despite publicly known intelligence advice that warned of the Indonesian intentions to try to hold the territory or, failing that, to destroy it.

We know now that President Habibie rejected the Australian advice to indefinitely delay an independence vote, and instead opted for an immediate referendum on independence. But the Australian government, ever with an eye on the opinion polling showing enormous public support for the Timorese, was happy to claim credit for this - and the media largely fell into line, and so a myth was born.

Reluctant Saviour helps set the record straight, showing that the Howard Government's efforts were designed 'to contain the forces of independence' ( $p$ 39). In this task, Fernandes uses sources available to any journalist - indeed all of his sources are from the public record.

Fernandes explains how a reformist President Habibie used Howard's letter as a catalyst for drawing support from his reluctant military who believed they could orchestrate a sham UN referendum in East Timor, just as 
they had done in West Papua 30 years earlier. He writes:

For the strategy to work, the Indonesian military needed a foreign ally to provide diplomatic cover in the international arena. Such an ally would run the propaganda line that East Timorese society was not united on the question of independence, but divided between rival factions so hostile towards each other that only the presence of the military was preventing a civil war ( $\mathrm{p} 47)$.

Fernandes concludes that 'the Howard Government filled this role of an ideal foreign ally. At every stage the Howard government's diplomacy worked in concert with the strategy of plausible denial, and functioned to reduce the prospect of international intervention' ( $\mathrm{p} 48$ ).

The book runs through the chronology of media reports of the time showing the Australian Government denying or minimising atrocities, and defending the Indonesian military. A series of intelligence leaks showed the media how they were being misled, but the Government continued to deflect calls upon the Indonesians to let in international peacekeepers.

Reluctant Saviour reveals the full nature of the Indonesian military's plans to subvert and overthrow the results of the ballot, by removing jour- nalists and the UN, then provoking open warfare with the Timorese resistance at the same time evacuating half of the population - what Fernandes, echoing Noam Chomsky, describes as 'the Carthaginian solution'.

Explaining why this did not occur is the book's paramount achievement. Buried under the Howard Government's myth of championing the independence of the East Timorese, is the story of activists' and the public's efforts to support the Timorese. (The book is devoted to the late Andrew McNaughtan, 'and his transnational family of activists'.) The deep support for the East Timorese always held by the Australian public found a focus - supporting the ballot result and demanding action from the Government.

Fernandes mounts a convincing argument that a combination of massive public concern, expressed partly in street rallies and in media talkback, and the mounting threat of massive union action against Indonesian interests, was roused by the organising efforts of seasoned activists, and the nightly reporting in the media.

Fernandes' descriptions of the rushed Defence response to set up an East Timor response team in a temporary conference room at Defence HQ a week after the ballot, shows just 
how quickly the Australian government policy position changed. Prudent military planning had prepared for the possibility of the peacekeeping operation, but absence of government policy for peacekeepers until the last moment had left the military scurrying to be ready.

The book makes use of information that has been made public in a little-reported 2002 Audit Office review of Defence's performance which found that 'the actual nature and size of the military operations to be undertaken were not clear until shortly before deployment' ( $p$ 109). Many of the military preparations, Fernandes points out, were in support of a short evacuation operation by the Australian defence force - shown for example by the scramble to find enough fresh food for the deployed forces rather than the new mission, of peacekeeping.

The success of the peacekeeping mission in taking over from the Indonesian occupation force and its ragtag militias has overshadowed a view of the reluctance of the Australian Government - an institutional reluctance which crumbled in the face of the overwhelming vote for independence, and the massive public support for the Timorese.

Reluctant Saviour presents for us a concise chronicle of the Howard
Liberal Government policy towards the Indonesian terror in East Timor. It debunks the fondly-held myth that the Government of the time urged and supported an independence referendum. It reminds us that the media must look behind such myth-making, and not forget the same Government has failed to push for the prosecution of the Indonesian perpetrators who are set to continue their handiwork in other areas of the Indonesian archipelago.

\section{Note}

Peter Cronau's documentary on Australian-Indonesian ties, Intelligence Wars, ran on ABC Radio in May 2004. The views in this article are his and do not represent the views of the $\mathrm{ABC}$ or the Four Corners programme.

pcronau@ hotmail.com

\section{References}

Howard, J. (1999). Transcript of speech by Prime Minister given at the official launch of the Millennium Forum, Sydney, November 30.

Senate References Committee on Foreign Affairs, Defence and Trade. (1999, December 9).Hansard, p 1028; cited in Reluctant Saviour, p 39.]

Text of Prime Minister Howard's Letter to President Habibie. (1998, December 19). Annex 2, East Timor in Transition 1998-2000: An Australian Policy Challenge. Canberra: Department of Foreign Affairs and Trade, 2001. 